\title{
Criminalization on Husband Wife Relationship towards Nushuz in the Perspective of Islamic Law and Criminal Code
}

\author{
Oom Mukarromah \\ IAIN Sultan Maulana Hasanuddin Banten \\ J1. Jendral Sudirman No. 30 Serang, Banten Province, Indonesia \\ E-mail: Oommukarromah1965@yahoo.com
}

Asep Ubaidillah

Al Ihsan Foundation Pandeglang Banten Indonesia

Indonesia

Received: October 25, 2016 Accepted: November 30, $2016 \quad$ Published: December 22, 2016

doi:10.5296/iss.v4i2.10494

URL: http://dx.doi.org/10.5296/iss.v4i2.10494

\begin{abstract}
The purpose of this study was to determine the criminalization law of nusyuz behavior both in Islamic law and the Criminal Code, and to know the relevance of Islamic law with the Criminal Code and Law No. 23 of 2004 in criminalization law of nusyuz behavior. The study used juridical normative approach in order to find the principle or the doctrine of positive law relevant to the issues studied, such as the opinions and ideas of jurists on the criminalization of the nusyuz behavior. This study used literature research method, which is a research conducted with data resources obtained from books or other writings relevant to the subject matter. The sources drawn from various works that discuss the problems of the family, the rights and protection of women, domestic violence and some literature on criminal law from the perspective of Islamic law and positive law. From the study, it can be concluded that: First, under the Islamic law, any form of physical violence against the wife is categorized in the form of jarimah (a criminal act) which is regulated in Islamic criminal law (fiqh jinayah). Second, in a substance, criminal law of physical violence against wife in the Domestic Violence Act is part of jarimah, a criminal act besides the soul. According to the Islamic criminal law, criminal act is classified into jarimah takzir.
\end{abstract}


Keywords: criminalization, husband, wife, nushuz, Islamic law and the criminal code 


\section{Introduction}

Marriage as a legal act between husband and wife is not only for the realization of human's worship towards Him, but, at the same time, raises consequences of civil law between the two. However, due to the noble purpose of marriage, that is to build a happy, eternal, and immortal family based on the divine of Almighty One, it is necessary to regulate the rights and obligations between each of them. If their rights and obligations are fulfilled, then the desired household life based by love and affection will be realized (Note 1).

The concept of a "family" usually cannot be discharged from the following four perspectives: (1) nuclear family; that the family consists of three main components, a husband, wife and children; (2) a harmonious family; (3) the family is the continuation of the generation; and (4) family is a marriage intact. From the four perspectives, it can be concluded that the household is a unit consists of father, mother (who are bound by marriage), children who are closely related to elements of grandparents and other relatives, all show their unity through harmony and clear roles (Note 2).

Ideally, every person who will have a family must expect happiness and harmony in the household. However, the reality does not always in line with the expectations. Tensions and conflicts often arise; disagreements, arguments, bickering, teasing or even curse become a common matter, and all of them should have been resolved wisely through deliberation, by opening dialogue within each other. In fact, there are many problems in the household which looks small and insignificant but can lead to disruption of the harmony of conjugal relations. Giving rise to what is commonly known in Islamic law as nusyuz.

All of this time, the issue of nusyuz is always associated with the wife, with the assumption that nusyuz is an attitude of non-compliance wife towards her husband. Therefore, in this case, the wife is always being the one to blame. Similarly, in the holy books of Fiqh, nusyuz is considered as if it were a special legal status which exists in women (wives) and therefore the men sides (husbands) are authorized with some rights in dealing with the disobedience wife. The first act allowed to be performed by a husband is to advise his wife, to keep asking her for sleeping together. Sleeping together is a symbol of harmony in the household. If the first action is not success, the husband may take a second action, which is sleep separately. If the second act is still not able to change the wife, the third act that the husband has to do is to hit her (Note 3). This is as described in the Qur'an Surah an-Nisa '(4): 34, that: Men are in charge of women by [right of] what Allah has given one over the other and what they spend [for maintenance] from their wealth. So righteous women are devoutly obedient, guarding in [the husband's] absence what Allah would have them guard. But those [wives] from whom you fear arrogance - [first] advise them; [then if they persist], forsake them in bed; and [finally], strike them. But if they obey you [once more], seek no means against them. Indeed, Allah is ever Exalted and Grand (Note 4).

In Islamic Law Compilation (KHI) itself, it is mentioned in Article 80 paragraph (7) that, "the duty of a husband as referred to in paragraph (2) is considered void if the wife is nusyuz" (Note 5). What is meant by duty here is the obligation to make a living, kiswah, and residence for the wife. As described in paragraph (4) in the same article, the actions performed by the 
husband seem to have become his sovereign right with legal justification to strengthen it, and he can do that whenever there is a suspicion of the wife does nusyuz. In a classic book there is a quote that states, "nusyuz is women who allegedly left his duty as a wife for his hatred toward her husband, like leaving home without the husband's permission and overbearingly against the husband (Note 6)."

Based on the issues stated above, clarification of law both in the perspective of Islam as well as Criminal Code and applicable positive law in Indonesia is necessary in order to avoid the presence of victims and each of the side can receive their own right, without discriminating any existing law. While the subject matters of this study are: How does the criminalization law of the nusyuz behavior according to the perspective of Islamic law and the Criminal Code; and what is the relevance between Islamic law with the Criminal Code and Law No. 23 Year 2004 on nusyuz behavior?

This study aims to: know the criminalization law of the nusyuz behavior both in Islamic law and the Criminal Code; and to know the relevance of Islamic law with the Criminal Code and Law No. 23 Year 2004 on nusyuz behavior. This study is expected to be used as follows: First, as a contribution to nusyuz matters in order to raise more justice values; Second, to enrich the science and knowledge of Islam, especially in the field of Islamic Family Law; Third, as consideration and input for legislators in formulating legal provisions, particularly those related to the efforts of legal protection for women on domestic violence.

\section{Literature Review}

The New Face of Spouse Relationship; Study of 'Uqud al-Lujjayn. This book is a critical study over the most popular 'Uqud al-Lujjayn book by Syaikh an-Nawawi. In discussing the rights of the husbands in treating their nushuz wives, the discussion begins by explaining the meaning of the an-Nisa '(4): 34. "And they separate from their beds", it means that husbands are encouraged to leave the wives of their beds, not to avoid talking and hitting. Because, separating from the bed gives clear impact in educating women. While the phrase "and hit them," means that is the nusyuz women it may be hit with harmless pressure to the body, and it is performed when it brings benefits to the spouse. If not, then hitting is not necessary. It will be better if the husbandforgives the wife (Note 7).

Women, Violence, and Law. The book written by Aroma Elmina Martha was preceded by a long explanation about the phenomenon of violence against women, including violence in the domestic household. Although the term violence against women itself is not used in the formulation of the law. Penal Code has put the issue of violence against women mostly in the chapters of crime and morality contained in chapter XIV. Similarly, Article 356 of the persecution of family members, including the wife is included in persecution chapter.

Articles 351, 352, 354 and 355, which are all set about persecution, exacerbated by adding a third of the ruling, if the offense was committed to his mother, father, wife (husband) or children. Specifically, domestic violence put as aggravating circumstances. In the Criminal Code itself, types of violence that has been governed more physical violence, such as pornography, rape, lewd acts, persecution, murder, and kidnapping. Further explained that a 
number of other physical abuse does not get any criminal sanctions, and the result is, despite the victimization of women, there is no other legal actions of the women's act, such as incest, marital rape and sexual harassment (Note 8).

\section{Methodology}

The study used library research method, i.e a study which data resources obtained from literature, books or writings that are relevant to the subject matter studied. The sources drawn from various works that discuss the problems of the family, the rights and protection of women, domestic violence and some literature on criminal law from the perspective of Islamic and positive law.

The study is analytic descriptive, used for inventory and critical identification through critical analysis through the classification process of the existing law, with the first objective of deciding the criteria of identification to the selection and sorting between positive norms, social norms, and non-law norms. Second, conducting correction of the identified norms as positive norms. Third, organizing the identified norms and collecting it into a comprehensive system (Note 9).

The technique used in the data collection is documentaries technique, i.e primary data collecting drawn from books which directly discussing the problems studied, and from secondary literature which implicitly discuss it but relevant enough to be cited as comparison.

While the method used for analyzing data, in order to acquire an adequate and valid data are qualitative method. In the implementation, the data gained were generalized, classified, and analyzed by using inductive and deductive reasoning. Inductive reason in the process is derived from premises in the form of existing law norms, and ends (temporarily) on the discovery of the law principles and doctrines. The application of the method begins from the efforts to reveal the law principles and doctrines of The Husband's Right Boundaries in Treating His Nusyuz Wife which has been available to be generalized, classified, and analyzed to discover a new, comprehensive and systematically, understanding. While deductive reasoning is used to implement the discovered in abstracto law norms to be used as the start point of observing and evaluating the in concreto law, i.e husband's treats which exceeding the border of his rights and the possible criminal sanction.

\section{Result}

\subsection{Husband Rights}

Even though the nusyuz matters do not come from the wife side only, but also from the husband side, the husband rights are more dominant and get juridical acknowledgment. It means that, both in law and reality, husband has always been in the winning side when the nusyuz happened, while the wife has always been the victim. Therefore, the husband rights need to be emphasized. 


\subsubsection{Persuasive and Physical Sanction Right}

In the interpretation of Ibnu Kasir, explained that if you are afraid your wives will become nusyuz, then give them advise, and separate yourself from bed. If your advise is not granted, then do not talk to them while still maintaining the relationship you have with them. If all of the treats are not success, you may hit them with powerless hit especially in the face and head area (Note 10). In this case, the steps of action that may be performed by a husband towards his nusyuz wife are:

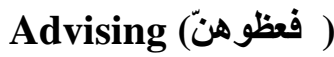

In treating the nusyuz matter, the first step to be taken as stated in the Al-Qur'an is by giving advice wisely to the wife. Of course, the advice given will be different to each wife, depending on the situation and condition they face, because within them there are sides who affected by secular sanctions, such as rejecting by others, while some do not receive that treatment.

It is better for the husband to remind his wife about the vow (misaqan galiza) tied between them two which cannot be fading due to emotional or logical problems. He also needs to explain any possible bad effect toward their relationship which will arise if the wife keeps continuing the nusyuz (Note 11). In the interpretation of al-Bahru al-Muhit, it is explained that in the effort of advising the nusyuz wife, also keep reminding her of Allah SWT command about the obligation to be obedient to the husband (Note 12). This is relevant with Abu Bakar Al-Jassas who stated that advising is frighten the wife with God's torture (Note $13)$.

\section{Sleep separately (واهجروهن)}

Hijr, according to Ibn 'Abbas as cited by As-Sabuni, is a husband's attitude in declining his wrist and diverting his back from his wife, and avoiding intercourse with her. Another opinion explains that hijr is a husband who leave his wife's bed and avoiding contact with her (Note 14). Therefore, the distance explained in hijr is limited only to physical contact, bedroom, or inside the house.

The ulama agreed to allow hijr through utterance that is not performed more than three days. The argument is based on the hadist of Abu Ayyub Al-Ansariy, where Rasullullah said:

لايحل لمسلم ان يهجر أخاه فوق ثلاث ليال(Note 15)

Regarding hijr, the statement does not give any explanation regarding the time limitation. Therefore, the ulama limit the time according to illa' (Note 16) law, which is 4 (four) months according to syara'. As explained in the Al-Qur'an:

$$
\text { للذين يؤلون من نسائهم تربص أربعة أثنهر فإن فاءو فإن الله غفوررحيم(Note 17) }
$$

And there is a condition of hijr where treatments such as avoiding the partner and intercourse, which can be performed without any time limitation, as wished by the husband, as long as the act is believed to be successful in reviving the wife, and does not more than four months in a row, because it is the maximum time period that is not allowed to be exceeded, as relevant 
with the strongest opinion from the law scholars. This matter is also explained in Tafsir alQurtubi, in which the husband is allowed to avoiding intercourse with his wife for four month in means of reviving her (Note 18).

\section{Hitting (واضريوهن)}

In the term hitting, fuqaha' defines it general understanding, that is an act that physically hurt, either leaves a scar or not, and uses a tool or not (Note 19).

Through further research, the word daraba derives from the phrase fi'il madidarabayadribu which has several meanings in Al-Qur'an:

1) In the phrase واضربو هن it is clear that fi'il amr is derived from fi'il madI which means hit, that is someone who throw something from his hand toward another person.

2) In the phrase وضرب الله مثنلا the word fi'il madI does not mean hit, but i'tibar (parable).

3) In the phrase عن اضرب بعصاك الحجر the word fi'il amar has the same meaning, hit. The difference lies in the use of tool in this phrase.

For fuqaha who contend about the permission of hitting, an-Nisa' (4):34 is used as the basis, which has historical chronology (sabab an-nuzul) as stated by az-Zamakhsyari in the story of Sa'ad ibn Ar-Rabi' ibn 'Amr and his wife Habibah binti Zaid ibn Abi as an event that underlying the phrase. It is told that Habibah was nusyuz to his husband Sa'ad, who was one of Ansar leaders. Then, Sa'ad hit Habibah and she reported Sa'ad's action to her father. The father then reported the problem to The Prophet. The Prophet advised her to avenge him equally. After that, surah An-Nisa (34) was revealed. After the surah was revealed, The Prophet said: "We expect a way, and Allah wants us to do another way. What He wants is the best way." (أردنا أمرا وأر اد اله أمراو الذى أراد الله خير). Therefore, the qisas punishment of the hitting was aborted (Note 20).

\subsubsection{Right to Prevent a Living}

Almost all scholars agree on preventing living for the nusyuz wife. However, they differed in determining the form and nature of nusyuz which causes the prevented livelihood. According to Abu Hanifah, a wife's right over livelihood will be fall if she leaves their home without permission of the husband, and for something that does not become a liability for her. Meanwhile, according to Imam Malik and Shafi'i, it does not cause the loss of the wife's right for a living (Note 21). The basis of a husband's refusal to provide livings for the nusyuz wife is based on the ijma of ulama (Note 22).

Ulama Hanafi argues that when the wife stay in her husband's house, and does not leave the house without the permission of her husband, then she is still called as obedience (muti'at), although she was not willing to be interfered without a right syara' reason. That kind of rejection, even if haram, does not terminate the right to earn a living. Therefore, he disagreed with all of the other scholars. For all the other scholars agreed that, when the wife does not give an opportunity to the husband for having intercourse with her without any reason either based on syara' or logical, she is seen as nusyuz woman who does not have right to earn a 
living. Even Shafi'i said that, a slight willingness of intercourse and khalawat, is not considered as sufficient if the wife does not offer herself to her husband, by saying firmly, "I give myself to you" (Note 23).

Imam Shafi'i argued that a wife who leaves the house without her husband's permission does not have any right to earn a living from her husband. In this case, Ibn Hazm argued that;

$$
\text { ومن طريق شعبة سألت الحكم ابن عنيبة عن امر أة خرجت من بيت زوجها غاضبة هل لها نفقة ؟ قال:نعم (Note 24) }
$$

And about the nusyuz wife, it has been described in the Qur'an an-Nisa 'verse 34. Based on the verse, Ibn Hazm said that:

God has informed us that it is not toward the nusyuz wife, except for hijr and hitting, and God does not abort the living and kiswah. Then you have tortured her by preventing her rights, and it has been legislated in the religion that is not permitted to do so (abort a living and kiswah) because it is batil (Note 25).

\subsubsection{Right to Divorce}

The Qur'an does not give a provision requiring the husband to put forward any reasons to use their rights to perform a divorce. However, a usual reason for a husband to divorce his wife is that he is no longer happy to be a husband of his wife. The reason is very subjective, which is also usually caused by subjective reasons (Note 26).

The existing legal system in our country is basically adheres to the principle that complicates the issue of divorce. As stated in Article 39 Paragraph (1) on Marriage Law No.1 of 1974, Article 14 to 18 of Government Regulation No. 9 of 1975 which decide that divorce can only be done in front of the court, and adequate reasons are necessary to conduct the divorce, that the husband and wife cannot live as harmonious and peaceful as before. The reasons that can be used as the basis for divorce are as described in the elucidation of Article 39 Paragraph (2) of Law No. 1 of 1974 and Article 19 of Government Regulation No. 9 of 1975 (Note 27).

In the Islamic Law Compilation (KHI), with regard to the reasons of divorce are as described in detail as follows (Note 28);

a. One party committing adultery or becoming drunks, compactor, gamblers and other refractory;

b. One party leaving the other side for 2 (two) years in a row without permission of other party and without valid reason or because of other things beyond his ability.

c. One party receiving jail terms of five (5) years or a more severe punishment after the marriage took place.

d. One party performing cruelty or maltreatment which causes serious harm to the other party.

e. One party getting disability or disease which causes them unable to perform their obligations as a husband or wife. 
f. There are a continual disputes and quarrels between the husband and the wife and there is no hope of living in harmony again in the household.

g. Husband violates divorce taklik.

h. Religion change or apostasy that cause disharmony in the household.

\subsection{Research Results}

\subsubsection{Criminalization in Nusyuz Context Based on Islamic Law}

The Qur'an talks about husband-wife relationship, as the relationship of partners and unlike the relationship seen between an employer and his maid. In domestic life, to achieve the purpose of family sakinah mawaddah wa Rahmah, one must understand how he acts in the household, as well as the knowledge of rights and obligations as a husband and wife to live a harmonious household life based on mutual respect.

In Encyclopedia of Islamic Law it is stated that a wife has the some authorities if she is faced by a nusyuz husband: first, be patient, the other way is to ask khul'a with a willingness to pay compensation to her husband so that her husband wants to drop the divorce (Note 29).

The husband who changes his attitude toward his wife, according Quraish Shihab, is also called nusyuz. Indeed, according to texts there is a difference between nusyuz committed by the husband and the wife in the case of the solution, even there is no further explanation of the law for nusyuz husband in the Marriage Law and the Compilation of Islamic Law. This is what has been suggesting the existence of inequality and gender inequality in nusyuz. On the one hand, when the problems arise from the wife side the responses are always seen as a serious problem and must be tackled immediately. Meanwhile, when it emerged from the husband, it is considered as something natural and is not overstated, and the wife should also try to be patient and to make peace with the husband.

Al-Qur'an in surah al-Nisa 'verse 128 offers a solution for a husband who conducts nusyuz, which is reconciliation by a wife towards her husband. This verse, according Quraish Shihab, gives an example of a wife or husband who gives or sacrifices some of his rights to his partner in order to avoid a divorce (Note 30).

In al-Asas fi at-Tafsir, Sa'id Hawa explains that making peace is better than a separation, nusyuz or any kind of hostility is considered as crime, otherwise reconciled is one of kindness. Sa'id cites paragraph ال شح الأز فس وأح ضرت (miser temperament). This means that if parsimony has already become a difficult character and inevitable, but they are still looking for a solution to get the benefit and expediency, then God will increase kindness and devotion. In these words there is a suggestion to avoid the ugly traits and to follow the advice of the syari'ah as Allah says: And if a woman fears from her husband contempt or evasion, there is no sin upon them if they make terms of settlement between them - and settlement is best. And present in [human] souls is stinginess. But if you do good and fear Allah - then indeed Allah is ever, with what you do, Acquainted (Note 31). 


\section{Mll Macrothink}

The point is that if you hate and do not love him/her, be patient on that circumstance. It is based on (to) maintain the rights and avoid seditious matters, turn away from anything that would lead into destruction and hostility. Asbab an-nuzul of this verse is Sa'id as cited by Sunan Sa'id bin Mansur from Uswah: Saudah was an old woman, then Sauda asked the Prophet (though it is hard) to provide the next ration (turn) to Aisha, because she knew the love of the Prophet to Aisha, then The Prophet accepted it (Note 32).

When nusyuz comes from the wife's side, the husband can take four steps of settlement. First, advise and admonish the wife after advising and introspect himself. Second, sleep separately and do not talk to each other. This step is not allowed to be performed more than three days or a maximum of four months according to illa'. Third, hitting. The ulama differed on the form of the hitting. as-Sabuni and Wahbah az-Zuhailiy said that the husband should not hit the face, stomach and keep hitting on one part only so that it can increase the pain. Imam Hanafi asserted, based on the hadits of Bukhari and Muslim, for this hit the husband uses no more than ten pieces of lidih (Note 33).

In Minhaj, as cited by al-Jamal (W.1204), it is stated that when it the signs of nushuz from the wife has emerged, the husband could advise her. When it has obviously convinced that she is nushuz, then the husband can sleep separately and hit her slowly (Note 34). The fourth step is to hold a peace agreement with the peacemaker. Peace is no longer a category in nushuz, but in syiqaq, that is the hatred which has colored both sides. For those parties who clearly distinguishes between nusyuz and syiqaq.

As a note to be kept in mind is that right or authority of the husband in treating wife who is nusyuz as described in the letter an-Nisa '(4): 34 , also his right to prevent a living for the wife and also the right to drop a divorce, all of them are given to men not for the purpose of husband as the one who authorize to punish, nor by considerations of his power as a leader, but it was given to him only as a educational method as well as solution in addressing the issues that arise in the household in accordance with the husband's function as a guardian, protector and a regulator for the good and benefit of both of them. This is in accordance with the rules of fiqh;

$$
\text { تصرف الإمام على الرعية منوط بالمصلحة (Note 35) }
$$

The authors assumed that the inequality regarding the relationship of husband and wife in the household is happening in our social life due to several factors. One of them is the culture construction of assumption that woman or wife is completely the right of a husband, and the wife is obliged to keep the problem of the family from others. Many of the victims who suffered in her household, wives who lost their rights as human beings who should be treated humanely.

To understand the reality of violence against wives as a form of violence against women a study based on the perspective of women is needed, because without the perspective, it will continue to be stuck in a range of myths (Note 36) that led to the preservation of women victimization culture. In fact, violence against wives is the greatest danger to women than the danger of violence in the streets. It is caused by several factors as described above. 


\section{Macrothink}

The issue of violence against wife itself cannot be separated from the cultural and religious context that tends to be patriarchal and the husband's morality. This is due to the domestic violence among Muslims nowadays, which is not based on the misunderstanding from the Verses of the Qur'an alone (Note 37), but also construction patriarchal cultures and religions that has led to various forms of negative effects of prejudice on the position and role of the wife (Note 38). The great religions in the world are basically legitimizes these views. In the Islamic world, for example, there are few things that provide opportunities for the husband to be able to marry another woman, and only with uttering talak for three times, then spouses are automatically legally divorced and there is no longer any reason for both sides to hold the referral back, except after the former wife remarried to another man and then divorced (Note 39).

\section{Discussion}

\subsection{Violence against Wives}

Actually, the violence committed by a husband is not entirely due to the opportunities presented by the patriarchal culture and religion, but can also be caused by the husband's morality. This aspect is quite reasonable, because there are some violence committed against wives came from the husband's abnormal behaviors, such as irregularities in sexual intercourse. The examples are sadism abnormality and masochism.

According to the author, violence against wives is due to:

1. The public perception that men have a higher position than women or wife, and the husband has the right to treat wives as they please.

2. The existence of mimicking behavior of a boy who saw his father's violence against the mother or see violence through television and other media so that he has a tendency to do the same against his partner later.

3. The existence of erroneous interpretation of religious teachings, for example, a husband may beat his wife if the wife is nusyuz. This teaching is often misunderstood as a justification for violence against wives.

Violence against wives is classified as a new theme in the field of social sciences, because feminism as the head of this concept is also relatively new. Violence against wives is violence perpetrated by husbands against wives (Note 40). Violence against wives is a part of domestic violence and domestic violence is a part of family violence.

Violence against wives (KTI) has four forms. First, physical violence such as hitting, slapping, spitting, pulling, kicking, lilting a cigarette, injuring with some objects and so on. Second, emotional violence such reproaching, insulting, speaking harshly, threatening or scaring as a means to impose the will to isolate the wife of the outside world and so on. Third, economic violence such as not giving a living, using or spending wife's money and so on. Fourth, sexual violence like a forced intercourse, forcing personal sexual preference, and does not pay attention to wife's satisfaction (Note 41). 


\section{Mll Macrothink}

Issues in Social Science

ISSN 2329-521X

2016, Vol. 4, No. 2

This KTI happens for several reasons. First, the culture that acknowledges the distinction of structural position in marital life. Determination of the husband's role as head of the household and the wife as homemaker provide opportunities for violations of women rights in marriage. All this time, the violation of the women rights in marriage is less audible because it was considered normal and ordinary. Most communities still hold a social norm that says that life in marriage (household) is a covered area or "just for personal entertainment". Cultural roots of the background for understanding the structural hierarchy are patriarchal culture (Note 42). Second, gender-biased understanding of religious teachings. An example of misunderstanding towards the meaning of nusyuz leads to an understanding of permission to beat the wife, without further study about it (Note 43). Third, the State policies that supports male supremacy over women like family planning (KB) policy that emphasizes women (wives) to use contraception, standardization of the Act that considers men as heads of households and women as housewives (Note 44).

An act is not considered as a crime unless it is established by syara' that the act is reprehensible. When syara' has decide that the act is reprehensible then the act is certainly a crime, regardless of the level, and this crime will be subject to sanctions.

Crime is also not something pure in human's soul, or "profession" that is cultivated by humans. It is also not a disease that afflicts humans. Crime is an act against the rules, whether the rules with his Lord, himself, and with other human beings. Thus, in Islam, homosexuals or masochism is a crime, not a mental illness especially human nature that cannot be denied.

In Islam, avoiding in hitting his wife is the priority, even if the husband has to hit, he should not hit on one part of her body only and avoid the face, because the face is a sign of honor and beauty. The hit is also not more than 10 times. Some argue the husband should use a handkerchief when hitting and the wife should not be hit with a whip or a cane. In general, a light hit was better in this matter (Note 45).

\subsection{Criminalization in Nusyuz Context According to KUHP}

There are three principles of criminalization that need to be considered by the legislators in defining an act as a criminal offense as well as the threat of criminal sanction, namely: (1) the principle of legality; (2) the principle of subsidiary, and (3) the principle of equality/similarity. First, the principle of legality, i.e the principles which essence contained in the statement: "there is no acts that can be imprisoned unless according the criminal law that existed before the act was committed". The principle of legality is the most important principle in criminal law, in particular in setting the basic principles of criminalization. According Schafmeister and J.E. Sahetapy (Note 46).

The principle of legality in the Indonesian Criminal Code is derived from the Wetboek van Strafrecht Nederland (WvS. Ned), as derived from the provisions of Article 8 of the Declaration des Droits de L'Homme Et Du Citoyen 1789, which states, 'no person can be imprisoned other than in the power of enactment existing legislation', and a view of Lafayette from America to France and sourced from the Virginia Bill of Rights in 1776. Barda Nawawi Arief said that "from the standpoint of positive Indonesian criminal law (criminal Code / WvS) 


\section{Ml Macrothink}

it is worth a question, because according to the Criminal Code (Article 1 Paragraph (2)), the problem of retroactive there is emerging only if there is a transition period (i.e if there are changes in the Act), not in terms of the new law. In the case of entirely new enforced laws, including the scope of the problem source of law set forth in Article 1 Paragraph 1 of the Criminal Code (the principle of legality formal) (Note 47).

Second, in addition to the principle of legality, the criminalization policy should also be based on the principle of subsidiary. That is, the criminal law should be placed as ultimum remedium (ultimate weapon) in the prevention of crime using the instrument penal and not as primum remedium (main weapon) to cope with the crime problem (Note 48).

Thirdly, there is another principle which also has an important position in the criminalization process, namely the principle of equality/similarity. Similarity is simplicity and clarity. Simplicity and clarity will give order. According to Servan and Letrossne, the principle of similarity is not an aspiration statement of a fairer criminal law. The principle of equality is rather a desire of holding of a clearer and simpler criminal justice system (Note 49).

The cases related to violence against wives in the household are included in these types of cases of persecution to lawsuits under Article 351 Paragraph (1) of Penal Code which contains the persecution punishable by a maximum imprisonment of two years and eight months or a maximum fine of three hundred million rupiah. Then, Article 351 Paragraph (2) which contains the persecution that resulted in serious injuries, and the offender threatened with imprisonment of five years and one case with Article 356 for the persecution of the wife, the perpetrator is punished according to Article 356 (persecution by weighting criminal) because the persecution was committed against the wife, husband, father, mother and son.

This persecution can also be used as an excuse for a wife to file a divorce under Article 19, Regulation No. 9 of 1975 and may lead to the fall of divorce according to sighat taklik pronounced by the husband shortly after the ceremony held. The problem is that, in practice, the existing legal protection is not effective due to various factors. One of them is because the legislators are less sensitive to women's interests and rights. Similarly, the nature of our society tends to blame women in several matters has hindered women to bring an action against the problem legally. In other words, if we speak on the level of protection to the victims of violence, we can say that justice is still far from the grasp of women. This occurs because of the persistence of gender assumptions and patriarchal values in both the substance of its legal substance, legal structure, and in public attitudes including the attitudes towards the women themselves (Note 50).

After the passing of the Law on the Elimination of Domestic Violence No. 23 of 2004 on 22 September in 2004, the efforts to eliminate domestic violence, especially against women, have gained a solid juridical foothold. Although the introduction and implementation process have not been maximized, at least now Indonesia has a clear legal devices and in particular regulate the protection of victims of domestic violence at the same penal provisions for perpetrators of the same level of violence. Therefore, it is expected that the occurrence of domestic violence against women in any form and reasons can be processed legally, so that the sense of justice can be obtained by the victims. 


\section{Mll Macrothink}

Issues in Social Science

ISSN 2329-521X

2016, Vol. 4, No. 2

There is an interesting thing when trying to bring nusyuz issue in Islam to Indonesian law context; it is due to the fact, first, that the majority of its population is Muslim. Second, civil law family also used Islamic law which contains provisions on nusyuz. Third, the strong domination of men against women in all sectors due to strengthens of patriarchal culture in social reality.

The purpose of the correlation of facts is to illustrate that, in our society, the issues of nusyuz, which is normally happening in domestic life, and will likely be the trigger for violence especially against the women due to the husband's rights and his authority in addressing or tackling the disobedience wife. And in this issue, the wife has been provided by a legal means to defend themselves and their rights under the law. As known that the right or authority of the husband on the nushuz wife, such as the right to avoid the wife, beat her, and prevent rights of living in the provisions of law in Indonesia as stipulated in Law No. 23 of 2004, all of them are part of the violence against wives which can be prosecuted and sentenced to criminal sanctions.

While the punishment for the perpetrators of domestic violence is expressly provided in chapter VIII of the penal provisions with a detailed explanation as follows; Anyone committing acts of violence within the domestic sphere as referred to Article 5 letter A shall be punished by

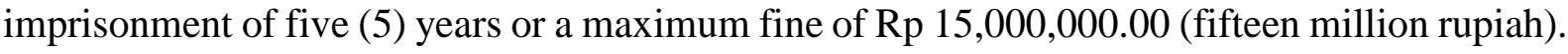
In terms of the act referred to paragraph (1) resulted in the victim gets sick or serious injury, shall be punished with imprisonment of ten (10) years or a maximum fine of $\operatorname{Rp} 30,000,000.00$ (thirty million rupiah). In terms of the act referred to paragraph (2) resulted in the death of the victim, shall be punished with imprisonment for a period of 15 (fifteen) years or a maximum fine of $\mathrm{Rp} 45,000,000.00$ (forty-five million rupiah). In the case of acts as referred to paragraph (1) committed by a husband against wife or vice versa that does not cause disease or obstructions to run the job position or livelihood or daily activities, shall be punished with imprisonment for a period of 4 (four) months or a maximum fine of Rp 5,000,000.00 (five million rupiah) (Note 51). And this type of criminal offense referred to in Article 51 is to a complaint of offense

\subsection{Relevance of Islamic Law with KUHP}

In addressing the issue of nusyuz, it needs to be addressed proportionally, which means that there should be one between a husband and wife who are able to understand the psychological condition of the partner who is currently being nusyuz, as well as making corrections to themselves and dare to plead guilty if they do, to establish an understanding among them. In other words, they should still seek for reconciliation by promoting the domestic life and their interests as well as their children. However, if the nusyuz are endless and feels more peaked that has led to the level of syiqaq or fight between husband and wife and is no longer possible to be resolved by peaceful means, a legal way such as divorce is a path that can be taken as the final solution. Moreover, when the fight resulted in the emergence of violence against one of the spouses, particularly the wives, then legal action in an attempt to guarantee the protection of victims and punishment of the perpetrators have to be properly adopted.

In Islam the husband shall establish interaction with the wife in makruf and therefore should not force the wife. The wife shall obey her husband as long as it does not lead to immoral acts. 
As an example, the wife may not refuse husband's invitation to have sexual intercourse except in conditions that are forbidden in syar'i. Sexual relations between husband in the emergency situation is khilaful aula (not in accordance with the main), but cannot be classified as rape. However, if acts of violence in criminalization or nushuz context as a trigger are indicated, the form of physical violence against the wife is categorized as jarimah (a criminal offense) regulated in Islamic criminal law (figh jinayah).

Jarimah in this case is a felony on a soul, according to the perspectives of Islamic criminal law, in substance the law of physical violence against wife in the Domestic Violence Act is part of jarimah. It is related to a sentence of imprisonment in the Domestic Violence Act, in accordance with Islamic criminal law, so that the criminal act is classified into jarimah takzir. One aspect in an effort to help victims of domestic violence is the law. Until now the law that is used or becoming reference of the law enforcement on cases of domestic violence is the Penal Code and the Criminal Code. The term used in those books concerning physical act is "abuse", while the term violence is recently used in Act No. 23 of 2004.

\section{Conclusion}

From the description of the discussion that has been elaborated in this study, it can be concluded that: First, In Islamic law, acts of criminalization or violence in the context of nusyuz or other forms of physical violence against the wife is categorized as jarimah (criminal acts) that arranged in Islamic criminal law (fiqh jinayah). Second, the relevance of Islamic law with the Positive Law in Indonesia of the term jarimah in this case is a felony over a soul. According to the perspectives of Islamic criminal law, in substance law the crime of physical violence against the wife as stated in the Domestic Violence Act is part of the jarimah, which means criminal sanction over a soul. In connection with a sentence of imprisonment in the Domestic Violence Act based on Islamic criminal law, the criminal act is classified into jarimah takzir.

\section{Acknowledgment}

Upon completion of this study, the authors would like to thank all parties who have helped the author in data collection on interviews and observations, and especially for the entire residents of Carenang Serang, Chairman of the District Office of Religious Affairs Carenang Serang, and the Head Officer of Religious Affairs Serang District. The author would also like to thank the colleagues, Head of the Graduate Studies Program in the Islamic State Institute Banten Sultan Maulana Hasanuddin who continues to provide encouragement, motivation and constructive criticism to the writer.

\section{References}

Abdurrahman. (1992). Kompilasi Hukum Islam di Indonesia. Jakarta: Akademika Pressindo.

Al-Bantani, T. N. (2012). Al-Qur'an Mushaf Al-Bantani dan Terjemahan,cet III. Bogor: Lembaga Percetakan Al-Qur'an Kementrian Agama RI.

Alimi, M. Y. (ed.). Sosialisasi Menjinakkan "Taqdir" Mendidik Anak Secara Adil,cet. I, Yogyakarta: LSPPA. 
An-Nawawi. (1981). Sahih Muslim bi Syarh an-Nawawi. Dar al-Fikr.

Arief, B. N. (1996). Bunga Rampai Hukum Pidana. Citra Aditya Bakti, Bandung.

Asy-Syahir, M. Y. (1993). Tafsir al-Bahr al-muhit, 8 Jilid. Beirut: Dar al-Kutub al-Alamiyah. bin Abdurrahman, M. (t.t.). Rahmah al-Ummah fi Ikhtilaf al-Aimmah.Surabaya: al-Hidayah. bin 'Umar Al-Ajily-Syafi'i al-Jamal, S. (1992). Al-Futuhat Al-Ilahiyat, Beirut: Dar al-Kutub al-Alamiyah.

Fakih, M. (1996). Analisis Gender dan Transformasi Sosial, Cet.I. Yogyakarta: Pustaka Pelajar.

Hasyim, S. (2001). Hal-hal yang Tak Terpikirkan tentang Isu-isu Keperempuanan dalam Islam, cet. III, Yogyakarta: Mizan.

ibn 'Ali Razi Al-Jassas, A. A. (1993). Ahkam Al-Qur'an. Bairut: Dar al-Kutub al-Alamiyah.

Latif, M. D. (1981). Aneka Hukum Perceraian di Indonesia, cet. II. Jakarta: Ghalia Indonesia.

Marta, A. E. (2003). Perempuan Kekerasan dan Hukum, cet. I. Yogyakarta: UII Press.

Mundzar, A. (2000). Wanita Dalam Masyarakat Indonesia. Yogyakarta: Sunan Kalijaga Press.

Nawawi bin Umar bin Arabi, M. (t.t.). Syarh Uqud al-Lujjayn fi Bayan al-Huquq az-Zawjayn, Surabaya: Mutiara Ilmu.

Nurhayati, E. (1999). Tantangan Keluarga pada Mellenium ke-3. dalam Lusi Margiani dan

Rida, M. R. (1993). Jawaban Islam terhadap Seputar Keberadaan Wanita, alih bahasa Abd. Haris Rifa'i, Surabaya: Pustaka Progresif.

Rofiq, A. (1998). Hukum Islam di Indonesia, cet. III. Jakarta: PT Raja Grafindo Persada.

Sa'Id bin Muhammad Ubbadi, A. (Na). Idlahu al-Qawaid al-Fiqhiyyah, cet III. Surabaya: al-Hidayah, t.t.

Sahetapy, J. E. (Ed.) (1996). Hukum Pidana. Yogyakarta: Penerbit Liberty.

Saleh, R. (1981). mengutip Antonie A.G. Peter, dalan Asas Hukum Pidana Dalam Perspektif, Jakarta: Aksara Baru.

Shihab,Q. (2000). Tafsir al-Misbah, Jakarta: Lentera.

Sunggono, B. (2001), Metodologi PenelitianHukum, cet. III. Jakarta: PT Grafindo Persada.

Triningtyasasih (ed.) (1997). Kekerasan Dalam Rumah Tangga, cet. I. Yogyakarta: Rifka Annisa' bekerjasama dengan Ford Foundation.

Undang-Undang Republik Indonesia Nomor 23 Tahun 2004 tentang Penghapusan Kekerasan Dalam Rumah Tangga. 


\section{Al Macrothink}

Issues in Social Science ISSN 2329-521X 2016, Vol. 4, No. 2

Usman al-Khasit, M. (1994). Sulitnya Berumah Tangga: Upaya Mengatasinya Menurut al-Qur'an dan Hadis, ilmu Pengetahuan, alih bahasa. Aziz Salim Basyarahil, Jakarta: GIP78.

Wadud, A. (Na). Family in Islam: Or Gender Relations by Any Other Name. dalam Zainah Anwar dan Rashidah Abdullah,.

Wahid, S. N. (2001). Forum Kajian Kitab Kuning (FK3), Wajah Baru Relasi Suami-Isteri; Tela'ah Kitab Uqud al-Lujjayn, cet. I. Yogyakarta: LKiS.

Note

Note 1. Ahmad Rofiq, Hukum Islam di Indonesia, cet. III, (Jakarta: PT Raja Grafindo Persada,1998), hlm. 181.

Note 2. Elli Nurhayati, "Tantangan Keluarga pada Mellenium ke-3" dalam Lusi Margiani dan Muh. Yasir Alimi (ed.), Sosialisasi Menjinakkan "Taqdir" Mendidik Anak Secara Adil,cet. I, (Yogyakarta: LSPPA,1999), hlm. 229-230.

Note 3. Syafiq Hasyim, Hal-hal yang Tak Terpikirkan tentang Isu-isu Keperempuanan dalam Islam, cet. III, (Yogyakarta: Mizan, 2001), hlm. 183.

Note 4. Tubagus Najib Al-Bantani, dkk, “Al-Qur'an Mushaf Al-Bantani dan Terjemahan”,cet III, (Bogor: Lembaga Percetakan Al-Qur'an Kementrian Agama RI, 2012),An-Nisa' (4): 34. hlm. 84

Note 5. Abdurrahman, “Kompilasi Hukum Islam di Indonesia”, Jakarta: Akademika Pressindo, 1992, Pasal 80 Ayat (7), hlm. 91

Note 6. Muhammad Nawawi bin Umar bin Arabi, Syarh Uqud al-Lujjayn fi Bayan al-Huquq az-Zawjayn, (Surabaya: Mutiara Ilmu, t.t.), hlm. 7.

Note 7. Shinta Nuriyah Wahid, dkk, Forum Kajian Kitab Kuning (FK3), Wajah Baru Relasi Suami-Isteri; Tela'ah Kitab Uqud al-Lujjayn, cet. I, (Yogyakarta: LKiS, 2001), hlm. 52.

Note 8. Aroma Elmina Marta, Perempuan Kekerasan dan Hukum, cet. I, (Yogyakarta: UII Press, 2003), hlm. 54.

Note 9. Bambang Sunggono, Metodologi PenelitianHukum, cet. III, (Jakarta: PT Grafindo Persada, 2001), hlm. 84-85.

Note 10. Imam Abi AL-Fida' Al-Hafiz Ibn Kasir, Tafsir., I: 466.

Note 11. Muhammad Usman al-Khasit, Sulitnya Berumah Tangga: Upaya Mengatasinya Menurut al-Qur'an dan Hadis, ilmu Pengetahuan, alih bahasa A. Aziz Salim Basyarahil, (Jakarta: GIP, 1994), hlm. 78.

Note 12. Muh. Yusuf Asy-Syahir, Tafsir al-Bahr al-muhit, 8 Jilid, Beirut: Dar al-Kutub al-Alamiyah, 1993 M/1413 H.II, hlm.251.

Note 13. AbiBakr Ahmad ibn 'Ali Razi Al-Jassas, Ahkam Al-Qur'an, (Bairut: Dar al-Kutub al-Alamiyah, 1415 H/1993 M.), II: 238. 


\section{Macrothink}

Note 14. Muhammad 'Ali as-Sabuni, Rawaiul Bayan., hlm. 367.

Note 15. An-Nawawi, Sahih Muslim bi Syarh an-Nawawi, (ttp. Dar al-Fikr, 1981 M/1401 H), XVI: $117-118$.

Note 16. Illa' adalah marahnya suami terhadap isteri sampai mengeluarkan sumpah untuk tidak mencampurinya (mengaulinya). Lihat, Muh. Rasyid Rida, jawaban Islam terhadap seputar keberadaan wanita, alih bahasa Abd. Haris Rifa'i, (Surabaya: Pustaka Progresif, 1993), hlm. 53.

Note 17. Tubagus Najib Al-Bantani, dkk, Al-Qur'an Mushaf Al-Bantani dan Terjemahan”, Al-Baqarah (2): 226, hlm. 36

Note 18. Saleh bin Ganim, Nusyuz, hlm. 52.

Note 19. Saleh bin Ganim, Nusyuz, hlm. 57.

Note 20. Az-Zamakhsyari, al-Kasysyaf., I: 524.

Note 21. Muhammad bin Abdurrahman, Rahmah al-Ummah fi Ikhtilaf al-Aimmah, (Surabaya: al-Hidayah, t.t.), hlm. 248.

Note 22. Sayyid Sabiq, Fiqh as-Sunnah, II: 279.

Note 23. Jawad Mugniyyah, Fiqh Lima Madzab, hlm. 76.

Note 24. Ibn Hazm, al-Muhalla., X: hlm. 89

Note 25. Ibn Hazm, al-Muhalla., X: hlm. 89

Note 26. M. Djamil Latif, Aneka Hukum Perceraian di Indonesia, cet. II, (Jakarta: Ghalia Indonesia, 1981), hlm. 43.

Note 27. M. Djamil Latif, Aneka Hukum Perceraian di Indonesia, hlm. 43.

Note 28. Abdurrahman, “Kompilasi Hukum Islam di Indonesia”, Jakarta: Akademika Pressindo, 1992, 91Pasal 116.hlm. 102

Note 29. Dewan Redaksi Ensiklopedi Hukum Islam, "Ensiklopedi Hukum Islam", Jakarta: PT. Ichtiar Baru Van Hoeve, 1993. hlm. 1355.

Note 30. Quraisy Shihab, Tafsir al-Misbah, (Jakarta: Lentera, 2000), hlm. 579.

Note 31. Tubagus Najib Al-Bantani, dkk, "Al-Qur'an Mushaf Al-Bantani dan Terjemahan", An-Nisa' (4): 128. hlm. 99.

Note 32. Sa'id Hawa, al-Asas fi Tafsir, cet. I, (Beirut:Dar as-Salam, 1405 H/1989 M.), II: 1194-1195.

Note 33. Ensiklopedi Hukum Islam, hlm. 1355.

Note 34. Sulaiman bin 'Umar Al-Ajily-Syafi'i al-Jamal, Al-Futuhat Al-Ilahiyat, (Beirut: Dar al-Kutub al-Alamiyah, 1416 H/1992 M.), I: 379. 


\section{I Macrothink}

Note 35. Abdullah Sa'Id bin Muhammad Ubbadi, Idlahu al-Qawaid al-Fiqhiyyah, cet. III (Surabaya: al-Hidayah, t.t.), hlm. 62.

Note 36. Beberapa mitos yang dijadikan landasan kekerasan terhadap isteri adalah isteri dipukul karena membantah, melawan suami, dan berbuat kesalahan besar, kekerasan hanya terjadi karena suami mabuk, kalah judi, gagal dalam pekerjaan, kekerasan ini juga hanya dilakukan oleh suami yang berperangai kasar. Pemukulan terhadap isteri semata-mata karena suami lepas kontrol atau marah, dan hal ini tidak akan terjadi jika suami-isteri beragama dengan baik dan taat. Lihat, ibid., hlm. 191-192.

Note 37. Amian Wadud, "Family in Islam: Or Gender Relations by Any Other Name", dalam Zainah Anwar dan Rashidah Abdullah, (ed.), Islam, hlm. 69.

Note 38. Amian Wadud, "Family in Islam: Or Gender Relations by Any Other Name", dalam Zainah Anwar dan Rashidah Abdullah, hlm. 76.

Note 39. Jhon Samson Sembiring, "Kekerasan Terhadap Isteri Antara Kultur, Agama dan Moralitas", dalam Nur Hasyim, (peny.), Menggugat, hlm. 148.

Note 40. Triningtyasasih (ed.), Kekerasan Dalam Rumah Tangga, cet. I, (Yogyakarta: Rifka Annisa' bekerjasama dengan Ford Foundation, 1997).

Note 41. Triningtyasasih (ed.), Kekerasan Dalam Rumah Tangga,hlm. 2.

Note 42. Triningtyasasih (ed.), Kekerasan Dalam Rumah Tangga, hlm. 5.

Note 43. Triningtyasasih (ed.), Kekerasan Dalam Rumah Tangga, hlm, 5

Note 44. Bandingkan dengan Mansour Fakih Analisis Gender dan Transformasi Sosial, Cet.I, (Yogyakarta: Pustaka Pelajar, 1996), hlm. 54.

Note 45. Shiddiq Khan, As-Sayyid, “Al-Qur'an dan As-Sunnah bicara Wanita”, hlm. 71

Note 46. J.E. Sahetapy (Ed.), Hukum Pidana, Yogyakarta: Penerbit Liberty, 1996, hlm. 6-7.

Note 47. Barda Nawawi Arief, "Bunga Rampai Hukum Pidana”, Citra Aditya Bakti, Bandung 1996, hlm. 88.

Note 48. Roeslan Saleh mengutip Antonie A.G. Peter, dalan Asas Hukum Pidana Dalam

Perspektif, Jakarta: Aksara Baru, 1981, hlm. 61

Note 49. Roeslan Saleh mengutip Antonie A.G. Peter, dalan Asas Hukum Pidana Dalam Perspektif, hlm.36-3

Note 50. Atho Mundzar, Wanita Dalam Masyarakat Indonesia, (Yogyakarta: Sunan Kalijaga Press, 2000), hlm. 137.

Note 51. Undang-Undang Republik Indonesia Nomor 23 Tahun 2004 tentang Penghapusan Kekerasan Dalam Rumah Tangga, Pasal 44 Ayat (1), (2), (3) dan (4). 